\title{
Daur Ulang Air Leri Dalam Mengurangi Limbah Rumah Tangga
}

\author{
Aminudin*1, Widi Hastomo ${ }^{2}$, Andri Maulana ${ }^{3}$ dan Fiedha Nasution ${ }^{3}$ \\ 1,2Program Studi Manajemen Fakultas Ekonomi Bisnis, ITB Ahmad Dahlan \\ 3,4Faradisa Islamic School, Pamulang \\ *e-mail : aminudinf196@gmail.com¹, widie.has@gmail.com²
}

\begin{abstract}
This community service aims to educate the community in Bambu Apus Pamulang to be more concerned about waste. Households are productive producers of waste, household waste water can be used as liquid organic fertilizer for hydroponic plants, the water content of leri is nitrogen, phosphorus, potassium, calcium, magnesium, sulfur, iron, and vitamin B1. Hydroponics is considered suitable for urban communities, because it does not require a large place, is relatively safe from insects and the harvest period can be controlled, the results are expected to be able to meet the nutritional needs of households with organic vegetables. These community service activities are carried out so that the community is aware of the importance of protecting the environment, starting with simple matters, providing information that households are able to process and utilize leri's waste water, and finally teaching the community members how to grow hydroponic vegetables to ensure the nutrition of families with organic vegetables independently.
\end{abstract}

Keywords: organic waste, iquid organic fertilizer, hydroponics

\begin{abstract}
Abstrak
Pengabdian masyarakat ini bertujuan untuk mengedukasi masyarakat di Bambu Apus Pamulang untuk lebih peduli terhadap sampah. Rumah tangga menjadi penghasil limbah produktif, air leri limbah rumah tangga mampu dijadikan pupuk organik cair untuk tanaman hidroponik, kandungan air leri yaitu nitrogen, phosfor, kalium, kalsium, magnesium, sulfur, besi, dan vitamin B1. Hidroponik dianggap cocok bagi masyarakat perkotaan, karena tidak membutuhkan tempat yang luas, relatif aman dari serangga dan masa panen dapat dikontrol, hasilnya diharapkan mampu mencukupi kebutuhan gizi rumah tangga dengan sayuran organik. Kegiatan pengabdian masyarakat ini dilakukan agar masyarakat sadar bahwa pentingnya menjaga lingkungan, dimulai dengan hal yang sederhana, memberikan informasi bahwa rumah tangga mampu mengolah dan memanfaatkan limbah air leri, dan yang terakhir mengajarkan kepada warga masyarakat cara menanam sayur hidroponik agar tercukupinya gizi keluarga dengan sayuran organik secara mandiri.
\end{abstract}

Kata kunci: Limbah organic, pupuk organik cair, hidroponik

\section{PENDAHULUAN}

Rumah tangga menjadi penghasil limbah produktif organik dan anorganik, salah satunya yaitu limbah cair bekas mencuci beras atau biasa disebut dengan air leri. Setiap keluarga yang mengkonsumsi nasi sebagai bahan pokok, produktif menghasilkan limbah air leri, banyak warga yang belum memanfaatkan limbah air leri untuk dijadikan pupuk cair(Dan and Selada 2013). Hal ini perlu dilakukan untuk mendaur ulang sampah atau limbah rumah tangga.

Air leri beras putih memiliki kandungan unsur hara yang dibutuhkan oleh tumbuhtumbuhan yaitu nitrogen, phosfor, kalium, kalsium, magnesium, sulfur, besi, dan vitmin B1 (Wijiyanti et al. 2019),(Hartus 2002). Kandungan air leri memiliki peranan yang cukup penting terhadap perkembangan dan pertumbuhan tanaman (Elya Bahar 2016). Fermentasi yang dilakukan terhadap air leri selama lima belas hari akan meningkatkan unsur hara, hal tersebut bisa digunakan sebagai pupuk organik cair (Wijiyanti et al. 2019).

Hidroponik menjadi sebuah solusi bagi masyarakat perkotaan yang ingin bercocok tanam dihalaman rumah yang terbatas tanpa menggunakan tanah(Istiqomah 2014). Manfaat budidaya tanaman secara hidroponik dibandingkan secara konvensional yaitu tanaman dapat berproduksi dengan kualitas dan kuantitas tinggi, dapat diusahan terus menerus tanpa tergantung musim tanam, dapat diterapkan pada lahan yang terbatas, pertumbuhan tanaman dapat dikontrol, tanaman jarang terserang penyakit karena terlindungi (Trina E. Tallei, Inneke F.M 2017). 
Proses pembuatan pupuk organik cair tersebut tergolong cukup mudah dan tidak membutuhkan biaya yang mahal, hasilnya bisa digunakan untuk pupuk tanaman hidroponik(Hendra, H. A., Andoko 2014). Target dari pemanfaatan limbah air leri rumah tangga menjadi pupuk organik cair sebagai upaya rumah tangga mampu mendaur ulang limbah cair, diawali dari kelompok masyarakat di RW 01 Kelurahan Bambu Apus Pamulang Tangerang Selatan. Hasilnya diharapkan dapat memberikan informasi bahwa rumah tangga mampu mendaur ulang limbah cair yang dihasilkan selama ini.

Berdasarkan pada analisis situasi di wilayah RW 01 Kelurahan Bambu Apus Pamulang Tangerang Selatan dapat diidentifikasi dan dirumuskan sebagai berikut; (a) Rumah tangga menjadi penghasil limbah cair yang produktif, (b) Rumah tangga disebut menjadi penghasil limbah cair yang produktif karena mayoritas dari masyarakat menjadikan nasi sebagai makanan pokok, proses dari beras menjadi nasi menghasilkan air leri, hal tersebut yang belum dimanfaatkan masyarakat di wilayah RW 01 Kelurahan Bambu Apus Pamulang Tangerang Selatan, (c) Rumah tangga mampu mengolah limbah cair secara mandiri Limbah menjadi masalah yang serius dan butuh penanganan yang komprehensif, rumah tangga menjadi salah satu penyumbang produksi limbah. Pengolahan limbah air leri dengan cara fermentasi dapat dilakukan oleh setiap rumah tangga, hal tersebut dapat menekan dampak negatif dari pembuangan limbah cair secara langsung terhadap lingkungan sekitar, (c) Kurangnya informasi tentang manfaat dari air leri, Air limbah leri yang dihasilkan setiap hari oleh warga yang sudah di fermentasikan dapat dimanfaatkan sebagai pupuk organik cair, hal tersebut menjadikan unsur hara meningkat, baik digunakan pada perkembangan dan pertumbuhan tanaman (d) Hidroponik sebagai penghasil tanaman organic, Masyarakat perkotaan dalam mencukupi kebutuhan sayur mayur organik dapat memanfaatkan tanaman hidroponik dengan pupuk organik cair. Hidroponik tidak membutuhkan lahan yang luas, tidak membutuhkan tanah dan bisa mengatur siklus panen, hal tersebut yang perlu dimanfaatkan masyarakat di wilayah RW 01 Kelurahan Bambu Apus Pamulang Tangerang Selatan.

Tujuan dilaksanakannya pengabdian masyarakat ini adalah sebagai berikut; (a) Membentuk kelompok mandiri dalam memproduksi pengolahan limbah air leri rumah tangga menjadi pupuk organik cair, (b) Menciptakan pengetahuan dan teknik pengolahan limbah air leri rumah tangga menjadi pupuk organik cair, (c) Meningkatkan pengetahuan dan kemampuan kelompok mitra dalam penerapan teknologi dan pengetahuan pada pengolahan limbah air leri menjadi pupuk organik cair, (d) Meningkatkan nilai yang tinggi dari limbah cair rumah tangga melalui proses fermentasi, (e) Meningkatkan pengetahuan kelompok masyarakat warga RW 01 Kelurahan Bambu Apus Pamulang Tangerang Selatan untuk mendaur ulang limbah air leri.

Adapun manfaat yang diperoleh dari pelaksanaan pengabdian masyarakat ini adalah sebagai berikut; (a) Meningkatkan kemampuan memproduksi pengolahan limbah cair rumah tangga menjadi pupuk organik cair yang benilai tinggi, (b) Mengembangkan pengetahuan dan teknik pengolahan limbah cair rumah tangga menjadi pupuk organik cair, (c) Meningkatkan gizi masyarakat melalui produksi sayur mayur organik dengan cara hidroponik dan pupuk organik cair, (d) Meningkatkan kesadaran masyarakat tentang dampak negatif limbah rumah tangga yang dibuang secara langsung terhadap lingkungan, (e) Meningkatkan kemampuan mendaur ulang limbah rumah tangga terhadap kepedulian lingkungan.

Khalayak sasaran atau mitra pengabdian masyarakat ini adalah kelompok pemuda warga RW 01 Kelurahan Bambu Apus Pamulang Tangerang Selatan

Air cucian beras menyimpan banyak nutrisi yang berguna untuk menyuburkan tanaman (Pertanian.go.id n.d.). Masih banyak warga yang belum mengetahui tentang manfaatnya, sehingga air cucian beras terbuang begitu saja. Disamping bahan yang dibutuhkan sudah tersedia dan kita peroleh secara gratis, air leri tersebut bisa dimanfaatkan sebagai poc. Air cucian beras mengandung banyak nurtisi penting bagi tanaman sekaligus mengandung bakteri baik. Air beras mengandung 90\% karbohidrat berbentuk pati yang penting untuk hormon auksin, alanin dan gibbereline pada tanaman, mengandung vitamin B1, vitamin $\mathrm{K}$, protein, besi, kalsium, fosfor, 
boron dan juga nitrogen. Air cucian beras akan membantu beberapa hormon yang ada pada tanaman sehingga bisa merangsang pertumbuhan pucuk daun, membawa makanan ke seluruh sel pada daun dan batang (Pertanian.go.id n.d.).

Pupuk Organik cair atau biada disebut dengan POC yaitu larutan hasil dari pembusukan bahan organik yang berasal dari sisa tanaman, kotoran hewan dan manusia yang kandungan unsur haranya lebih dari 1 unsur. Kelebihan POC adalah dapat secara cepat mengatasi defisiensi hara, tidak bermasalah dalam pencucian hara dan mampu menyediakan hara secara cepat. POC ini tidak merusak tanah walaupun digunakan sesering mungkin. Larutan ini juga memiliki bahan pengikat sehingga dapat langsung diberikan ke permukaan tanah dan digunakan oleh tanaman. POC selain berfungsi sebagai pupuk dapat sebagai aktivator untuk membuat kompos (bppsdmp.pertanian.go.id n.d.).

Menurut laman dari (bppsdmp.pertanian.go.id n.d.) manfaat POC diantaranya yaitu; (a) Untuk menyuburkan tanaman, (b) Untuk menjaga stabilitas unsur hara dalam tanah, (c) Untuk mengurangi dampak sampah organik di lingkungan sekitar

Hidroponik atau istilah asingnya hydroponics, adalah istilah yang digunakan untuk menjelaskan beberapa cara bercocok tanam tanpa menggunakan tanah sebagai tempat menanam tanaman. Hidroponik berasal dari bahasa Latin yang terdiri dari kata hydro yang berarti air dan kata ponos yang berarti kerja. Jadi definisi hidroponik adalah pengerjaan atau pengelolaan air yang digunakan sebagai media tumbuh tanaman dan tempat akar tanaman mengambil unsur hara yang diperlukan. Umumnya media tanam yang digunakan bersifat poros, seperti pasir, arang sekam, batu apung, kerikil, rockwool (Chaidirin 2007).

\section{METODE}

Metode yang digunakan untuk mengatasi masalah yang dihadapi oleh khalayak sasaran (mitra) adalah dengan pendekatan Partisipatory Rural Apprasial (PRA), merupakan suatu metode pendekatan dalam proses pemberdayaan dan peningkatan partisipasi masyarakat, yang tekanannya pada keterlibatan masyarakat dalam keseluruhan kegiatan pembangunan.

Tahapan-tahapan pelaksanaan kegiatan pengabdian terdiri dari penyuluhan, pelatihan dan praktek langsung serta evaluasi. Tahapan tersebut dapat digambarkan sebagaimana Gambar sebagai berikut:

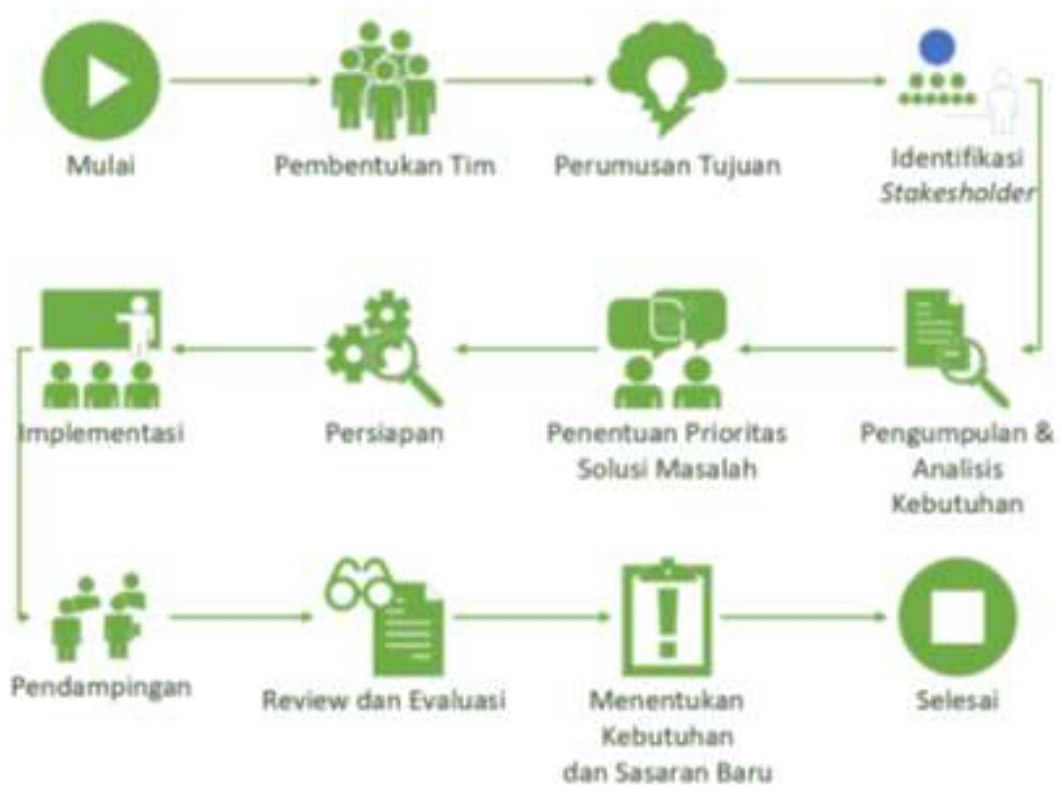

Gambar 1. Metode dan Pelaksanaan Pengabdian Masyarakat 
1. Tahapan awal dalam pengabdian masyarakat ini yaitu pembentukan Tim, kerjasa sama antara dosen Institut Teknologi Bisnis Ahmad Dahlan.

2. Dalam perumusan tujuan yaitu program pengabdian masyarakat yang diadakan oleh Institut Teknologi Bisnis Ahmad Dahlan adalah salah satu Tridharma perguruan tinggi.

3. Stakeholder dalam pengabdian masyarakat ini yaitu;

a. Internal stakeholder $\rightarrow$ Institut Teknologi Bisnis Ahmad Dahlan, LP3M dan Dosen.

b. Eksternal stakeholder $\rightarrow$ RT 01 dan RW 01, pihak dari Kelurahan Bambu Apus Pamulang Tangerang Selatan, pemuda-pemudi warga RW 01 Kelurahan Bambu Apus

4. Pengumpulan dan analisis kebutuhan;

a. Rumah tangga menjadi penghasil limbah yang produktif karena mayoritas mengkonsumsi nasi, dari proses beras menjadi nasi menghasilkan limbah cair.

b. Masyarakat belum mengetahui tentang manfaat limbah air leri dapat dimanfaatkan menjadi pupuk organik cair.

c. Keterbatasan lahan pekarangan di perkotaan bukan menjadi kendala untuk bercocok tanam, sangat cocok dengan tanaman hidroponik. Tanaman sayur mayur organik dari hidroponik dapat meningkatkan taraf gizi masyarakat.

d. Limbah cair rumah tangga yang dibuang langsung tanpa ada proses pengolahan atau fermentasi akan berdampak negatif terhadap lingkungan.

e. Rumah tangga diharapkan mampu mendaur ulang limbah yang dihasilkannya.

5. Penentuan Prioritas Solusi Masalah

a. Membentuk kelompok pemuda \& pemudi RW 01 dalam memproduksi pengolahan limbah cair rumah tangga menjadi pupuk organik cair yang benilai tinggi.

b. Menciptakan pengetahuan dan teknik pengolahan limbah cair rumah tangga menjadi pupuk organik cair.

c. Meningkatkan pengetahuan dan kemampuan kelompok mitra dalam penerapan teknologi dan pengetahuan pada pengolahan limbah cair menjadi pupuk organik cair;

d. Meningkatkan nilai yang tinggi dari limbah cair rumah tangga melalui proses fermentasi.

e. Meningkatkan kesejahteraan gizi kelompok pemuda \& pemudi warga RW 01 Bambu Apus melalui tanaman Hidroponik organik.

6. Persiapan $\rightarrow$ Hal yang perlu dipersiapkan dalam pengabdian masyarakat ini yaitu Air leri, Gula Merah, Air kelapa tua, Ragi tape dan Cairan EM4.

7. Implementasi $\rightarrow$ Pelatihan dilakukan dengan implementasi ilmu pengetahuan dan teknologi yang diperoleh dari kegiatan penyuluhan melalalui praktek langsung. Dalam hal ini pelatihan yang diberikan adalah bagaimana melakukan pembuatan pupuk organik cair. Selain dibekali dengan praktek pembuatan pupuk organik cair, mitra diharapkan mampu mendaur ulang sampah rumah tangga sendiri.

Setelah kegiatan pelatihan selesai dilaksanakan, langkah selanjutnya adalah mitra mempraktekkan pengetahuannya tentang pembuatan pupuk organik cair hasil dari proses kegiatan penyuluhan dan pelatihan sebelumnya. Kegiatan praktek ini dilakukan antara mitra dengan pelaksana pengabdian. Dengan pola ini diharapkan transfer ilmu pengetahuan dan teknologi mudah diserap dan dipraktekan oleh mitra.

8. Pendampingan $\rightarrow$ Dilakukan utamanya dalam kegiatan pelatihan dan praktek pembuatan pupuk organik cair. Pendampingan dilakukan dengan kegiatan konsultasi (tanya jawab) atas permasalahan yang dihadapi mitra selama dan setelah pelaksanaan kegiatan pengabdian 
masyarakat. Implementasi pendampingan pasca kegiatan pengabdian adalah dengan komunikasi jarak jauh (via aplikasi WA) dan kunjungan langsung oleh pelaksana kegiatan kepada mitra, untuk memastikan kegiatan ini benar-benar dilaksanakan dan menghasilakan apa yang diharapkan.

9. Review dan Evaluasi $\rightarrow$ Dilakukan pada setiap kegiatan dilapangan dan pasca kegiatan. Kegiatan ini dilakukan untuk memastikan kegiatan dapat berjalan lancar sesuai dengan rencana yang telah ditentukan sebelumnya. Evaluasi ini dilaksanakan baik pada saat kegiatan pengabdian mapun pasca pengabdian.

10. Menentukan Kebutuhan dan Sasaran Baru $\rightarrow$ Harapannya yaitu pengabdian seperti ini tidak hanya di masyarakat RW 01 Bambu Apus tapi lebih luas scope nya.

Kegiatan evaluasi pengabdian masyarakat dilakukan untuk mengetahui efektifitas atau keberhasilan kegiatan pengabdian masyarakat dilakukan. Kegiatan ini dilakukan setelah kegiatan pengabdian selesai dilaksanakan. Keberhasilan atau efektivitas kegiatan dapat dilihat dari capaian-capaian kegiatan berdasarkan indikator-indikator tertentu. Adapun indikator capaian dalam kegiatan pengabdian masyarakat ini adalah sebagai berikut:

Tabel 1. Tabel Evaluasi Kegiatan

\begin{tabular}{|c|c|c|c|}
\hline No. & Indikator Keberhasilan & Sumber Data & Instrumen \\
\hline 1 & $\begin{array}{l}\text { Meningkatnya pemahaman mitra tentang } \\
\text { pembuatan pupuk organik cair }\end{array}$ & Primer & $\begin{array}{l}\text { Persepsi mitra melalui } \\
\text { pertanyaan kuesioner } \\
\text { dan/atau wawancara }\end{array}$ \\
\hline 2 & Mitra mampu membuat pupuk organik cair & Primer & Pengamatan langsung \\
\hline 3 & Adanya hasil pupuk organik cair & Primer & Pengamatan langsung \\
\hline 4 & $\begin{array}{l}\text { Mitra mampu bercocok tanam dengan } \\
\text { Hidroponik dengan pupuk organik cair }\end{array}$ & Primer & Pangamatan langsung \\
\hline 5 & $\begin{array}{l}\text { Meningkatnya pengetahuan mitra untuk } \\
\text { mendaur ulang sampah cair rumah tangga. }\end{array}$ & Primer & Pangamatan langsung \\
\hline
\end{tabular}

\section{HASIL DAN PEMBAHASAN}

Air cucian Beras menyimpan banyak nutrisi yang berguna untuk menyuburkan tanaman. Sayangnya, tidak banyak yang mengetahui tentang manfaat ini, sehingga air cucian beras terbuang begitu saja. Disamping bahan yang dibutuhkan sudah tersedia dan kita peroleh secara gratis, tentu kita akan merasa bangga melihat tanaman kita tumbuh subur dan segar dari hasil olahan pupuk secara mandiri.

Air beras banyak manfaat air beras untuk tanaman yang mungkin belum banyak diketahui. Air cucian beras mengandung banyak nurtisi penting bagi tanaman sekaligus mengandung bakteri baik. Air beras mengandung 90\% karbohidrat berbentuk pati yang penting untuk hormon auksin, alanin dan gibbereline pada tanaman, mengandung vitamin B1, vitamin $\mathrm{K}$, protein, besi, kalsium, fosfor, boron dan juga nitrogen. Air cucian beras akan membantu beberapa hormon yang ada pada tanaman sehingga bisa merangsang pertumbuhan pucuk daun, membawa makanan ke seluruh sel pada daun dan batang (Pertanian.go.id n.d.).

Manfaat dari poc yaitu; (a) Mengandung Zat Pati, (b) Menghambat Pertumbuhan Patogen, (c) Mengurangi Syok Transplantasi, (d) Sumber Energi, (e) Membantu Proses Fotosintesis, (f) Mencegah Tanaman Layu, (g) Mempercepat Pertumbuhan Bunga. 
Bahan Pupuk Cair dari Air Cucian Beras, Alat dan bahan; (a) Air cucian beras sebanyak 10 L, (b) Cairan em4, (c) Gula merah sebanyak 1 / 4 kg, (d) Air kelapa tua sebanyak 1 L (jika tersedia), (e) Ragi tape 1 butir (jika tersedia), (f) Tempat tertutup seperti ember, tong atau jirigen dan dengan kapasitas sebanyak 15 L sebagai tempat penampungan, (g) Kayu atau bambu sebagai pengaduk.

Cara Membuat :

1. Masukkan air cucian beras yang sudah tersedia ke dalam tempat penampungan.

2. Ambil sekitar $100 \mathrm{ml}$ cairan em 4, kemudian masukkan ke dalam tempat penampungan yang telah berisi air cucian beras.

3. Masukkan pula parutan gula merah ke dalam tempat penampungan.

4. Masukkan air kelapa tua.

5. Hancurkan ragi tape dengan cara menumbuknya, lalu masukkan ke tempat penampungan.

6. Aduk semua bahan tersebut hingga rata dan jadi satu.

7. Tutup tempat penampungan tersebut rapat-rapat, diamkan untuk beberapa saat atau kurang lebih 7 - 10 hari.

8. Buka tutup wadah penampungan, dan apabila terdapat belatung atau ulat, berarti proses pembuatan pupuk dari air cucian beras telah berhasil. Pupuk pun sudah dapat diaplikasikan pada tanaman hidroponik

\section{Cara aplikasi Pupuk Organik Cair [POC] dari Air Cucian Beras}

1. Pemakaian POC dari cucian air beras dapat langsung di tuangkan dekat akar, atau disiramkan ke seluruh bagian tanaman dan ditempatkan penampungan air hidroponiknya.

2. Pupuk cair ini tidak hanya dipakai untuk pemenuhan nutrisi lanjutan pada tanaman muda atau telah dewasa dan siap berbunga, namun dapat pula diaplikasikan sebagai pupuk awal atau diberikan pada saat persemaian bibit tanaman.

3. Caranya adalah dengan menggunakan semprotan air agar tidak mengganggu atau merusak bibit tanaman yang masih rapuh, jangan lupa untuk menyaringnya terlebih dahulu.

\section{KESIMPULAN}

Hasil dari abdimas ini tidak hanya fokus membuat poc, akan tetapi;

1. Mengedukasi warga di kawasan Bambu Apus Tangerang Selatan agar tidak membuang limbah secara langsung,

2. Rumah tangga mampu mendaur ulang limbah air leri menjadi poc,

3. Memberikan informasi kepada masyarakat dalam membuat hidroponik dan memanfaatkan poc sebagai nutrisi tanamannya,

4. Masyarakat dapat mencukupi gizi keluarga dari sayuran organik hidroponik.

Kegiatan positif seperti ini mampu memberikan manfaat yang nyata dan berkesinambungan, serta ikut serta dalam mengurangi limbah sampah dan menciptakan lingkungan yang sehat.

\section{DAFTAR PUSTAKA}

bppsdmp.pertanian.go.id. n.d. "Pupuk Organik Cair." Retrieved (https://bbppbatu.bppsdmp.pertanian.go.id/pupuk-organik-cair/). Chaidirin, Y. 2007. Teknologi Greenhouse Dan Hidroponik. IPB Bogor. 
Dan, Pertumbuhan and Hasil Selada. 2013. "Pengaruh Air Cucian Beras Merah Dan Beras Putih Terhadap Pertumbuhan Dan Hasil Selada (Lactuca Sativa L.)." 1(2):24-35.

Elya Bahar, Angga. 2016. "Pengaruh Pemberian Limbah Air Cucian Beras Terhadap Pertumbuhan Tanaman Kangkungdarat ( Ipomoeareptans Poir ) Untuk Memenuhi Persyarat Guna Memperoleh Gelar Sarjana Pertanian Pada Fakultas Pertanian Universitas Pasir Pengaraian Oleh : ANGGA ELYA BAHAR."

Hartus, Tony. 2002. Berkebun Hidroponik Secara Murah. Pebenar Swadaya.

Hendra, H. A., Andoko, A. 2014. Bertanam Sayuran Hidroponik Ala Paktani Hydrofarm. Jakarta: AgroMedia Pustaka.

Istiqomah, S. 2014. Menanam Hidroponik. Jakarta: Azka press.

Pertanian.go.id. n.d. "Pupuk Organik Cair." Retrieved (http://cybex.pertanian.go.id/mobile/artikel/76293/Pupuk-Organik-Cair--POC--Dari-AirCucian-Beras/).

Trina E. Tallei, Inneke F.M, Rumengan Ahmad A. Adam. 2017. Hidroponik Untuk Pemula. Vol. 1.

Wijiyanti, Pipit, Endah Dwi Hastuti, Sri Haryanti, Program Studi Biologi, Departemen Biologi, and Universitas Diponegoro. 2019. "Buletin Anatomi Dan Fisiologi Volume 4 Nomor 1 Februari 2019 Pengaruh Masa Inkubasi Pupuk Dari Air Cucian Beras Terhadap Pertumbuhan Tanaman Sawi Hijau ( Brassica Juncea L .) Effect Of Fertilizer Incubation Period Of Rice Wash Water On Green Mustard Plant Growth ( Brassica Juncea L .)." 4. 